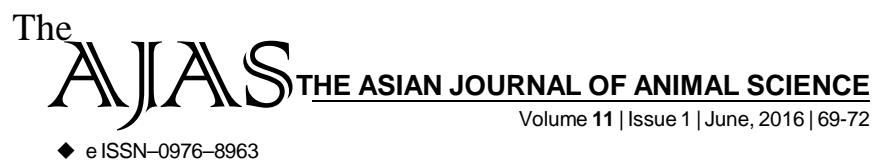

DOI : 10.15740/HAS/TAJAS/11.1/69-72 Visit us | www.researchjournal.co.in $\mathrm{S}$

A CASE STUDY

\title{
Constraints and training needs experienced by the rural women functioning in dairy farming practices
}

RUPENDER KAUR AND U.K. MEEL

Author for Corresponding -

\section{RUPENDER KAUR}

Krishi Vigyan Kendra (ICAR-DRMAR), Bansur, ALWAR (RAJASTHAN) INDIA

Email: ext_rupender@

rediffmail.com

See end of the article for

Coopted authors'
ABSTRACT...... The dairying has been considered as a potential means of alleviating large scale unemployment, especially in rural areas. In order to increase the efficiency of Indian rural women, training in dairy farming practices is very necessary. It is the function of helping other to acquire and apply knowledge, skill abilities and attitude which to do not possess, but which are needed. The study was conducted five societies from randomly selected five blocks of Bikaner district of Rajasthan with 120 respondents were selected randomly with the help of probability proportion technique. Findings of the study shows that the location of Artificial insemination centres at distance places, feed and fodder requirement of crossbred cow is more than deshi cow, excessive burden of work and responsibility, rearing of crossbred cow is very costly and easy selling of milk to the vendors as compared to society were observed as very serious constraints and the training is essential for rural women to overcome the constraints in performing their major role in dairy farming practices.

KEY WORDS....... Constraints, Training needs, Experienced, Rural women functioning, Dairy farming practices

HOW TO CITE THIS ARTICLE - Kaur, Rupender and Meel, U.K. (2016). Constraints and training needs experienced by the rural women functioning in dairy farming practices. Asian J. Animal Sci., 11(1): 69-72 (DOI : 10.15740/HAS/TAJAS/11.1/69-72).

ARTICLE CHRONICLE - Received : 30.12.2015; Accepted : 26.05.2016 